\title{
Psychosocial aspects in socioenvironmental disasters of geoclimatic origin: an integrative literature review
}

\author{
Aspectos psicossociais em desastres socioambientais de origem \\ geoclimática: uma revisão integrativa da literatura
}

Milena Maciel de Carvalho', Simone Santos Oliveira'

DOI: $10.1590 / 0103-11042020 E 223 \mid$

\begin{abstract}
Among the many crossings that permeate the conjuncture of a disaster, the psychosocial aspects deserve highlighting, because they include the cultural, social, structural, psychic, health, and symbolic issues. The aim of this review is to present how these aspects have been explored in the scientific literature in the last 20 years (1997-2016) by authors and journals from South American countries, in contexts of socioenvironmental disaster of geoclimatic origin. A bibliographic survey was conducted in the electronic databases Capes, SciELO, Latindex, and Virtual Health Library Portal. Taking into account the inclusion and exclusion criteria adopted in this review, 52 publications constituted the final sample. The survey revealed the predominance of 'mental health', 'psychosocial and health impacts', 'public health' and 'risk management' themes. The results showed evidence of social inequality as a potentiating factor of disasters and the inefficiency of public policies in Brazil in reducing disaster risks. Also, they revealed the predominance of studies that associate psychosocial support with interventions restricted to the field of mental health. As an opposite case, the article presents the construction of Chilean identity and public policies due to the earthquakes that occurred in the country.
\end{abstract}

KEYWORDS Disasters. Climate change. Psychosocial impact. Psychosocial support systems. South America.

RESUMO Dentre os inúmeros atravessamentos que permeiam a conjuntura de um desastre, os aspectos psicossociais merecem destaque por incluírem questões culturais, sociais, estruturais, psíquicas, sanitárias e simbólicas. O objetivo desta revisão foi apresentar como esses aspectos têm sido explorados na literatura científica nos últimos 20 anos (1997-2016) por autores e periódicos de países da América do Sul, em contextos de desastre socioambiental de origem geoclimática. Foi realizado levantamento bibliográfico nas bases eletrônicas Capes, SciELO, Latindex e Portal da Biblioteca Virtual em Saúde. Levando-se em conta os critérios de inclusão e exclusão adotados nesta revisão, 52 publicações constituíram a amostra final. O levantamento revelou a predominância das temáticas 'saúde mental', 'impactos psicossociais e na saúde', 'saúde pública' e 'gestão de riscos'. Os resultados evidenciaram a desigualdade social como fator potencializador de desastres e a ineficiência de políticas públicas no Brasil para a redução de riscos de desastres, bem como o predomínio de estudos que associam o apoio psicossocial a intervenções restritas ao campo da saúde mental. Como caso oposto, o artigo apresenta a construção da identidade e das políticas públicas chilenas em função dos terremotos ocorridos no País.

1 Fundação Oswaldo Cruz (Fiocruz) - Rio de Janeiro (RJ), Brasil.

milenafiocruz@gmail.com
PALAVRAS-CHAVE Desastres. Mudança climática. Impacto psicossocial. Sistemas de apoio psicossocial. América do Sul. 


\section{Introduction}

The world population has followed, particularly over the last 20 years, an increase in the number of people affected by socio-environmental disasters. This scenario reflects the contemporary socio-political and economic conjuncture of the planet, added to environmental and educational issues. This statement is based on data from the main assistance and development agencies worldwide, such as the United Nations (UN) ${ }^{\mathbf{1}} \mathbf{3}$, the World Bank $\mathbf{4}^{\mathbf{a}}$ and the World Health Organization (WHO) ${ }^{5}$, as well as information from reference bodies on climate change studies ${ }^{\mathbf{6}, 7}$ and in international scientific production ${ }^{8-11}$.

It has been observed that social vulnerability is an element present in places affected by phenomena of natural origin that culminated in disasters. Therefore, socio-political and economic issues play a determining role in the impact of extreme events, since almost all countries affected by disasters are underdeveloped ${ }^{\mathbf{1}-\mathbf{4}, \mathbf{7}}$.

At the same time, there is a major current debate regarding the increase in the frequency and magnitude of extreme weather events. According to the report 'The Global Climate 2011-2015' by the World Meteorological Organization (WMO), published at the 22nd Annual Climate Change Conference (COP22) held in Morocco in 2016, there was, in fact, an increase in the frequency of extreme weather events in Planet. This document highlights drought and high heat waves as extreme events, which drew attention due to the increase in their frequency ${ }^{\mathbf{1 2}}$, and reviews all the extreme events gathered in the Bulletin of the American Meteorological Society, which took place from 2011 to 2015, a period that was historically peculiar. They are mentioned as emblematic events during this period: the melting of ice in the Arctic Sea, the extreme drought that caused the death of thousands of people in the Horn of Africa, Hurricane Sandy in 2012, typhoon Haiyan (Yolanda) in 2013 in the Philippines, waves heat in Argentina and Australia and floods in Asia. Regarding Brazil, the report mentions the analysis of three extreme events: the floods and landslides in the mountainous region of the state of Rio de Janeiro in 2011, the severe drought between the years 2013 and 2014, responsible for the water crisis in São Paulo, and the drought in the Amazon in the years 2014 and $2015^{12}$.

Mata-Lima et al..$^{10}$ indicate that the studies carried out in the last 20 years have consistency in demonstrating and forecasting an increase in both the frequency and intensity of socio-environmental disasters, especially those related to the weather. In addition, they show the relationship between this type of disaster and the socioeconomic level of the affected countries.

A convergent point in the discussions on this theme is the need for nations to act in a planned, structured and educational way in preventing and responding to the impacts of climatic phenomena $\mathbf{2}^{\mathbf{2}, \mathbf{6}, \mathbf{1 0}}$. This preventive stance is imposed not only in the face of disasters related to the climate, but to all extreme events that put the routine and life of the communities at risk and exceed their capacity to respond.

These and other debates have led to the expansion of studies on the intervention process in situations of disaster and emergency, enabling the optimization of practices and the recognition of the importance of different social sectors, disciplinary fields and the community itself in planning actions in these episodes. In this sense, considering the importance of this joint articulation and interventions based on damage prevention, issues related to the impact and psychosocial support in disasters are configured as a fundamental strategy for prevention, response and recovery.

According to the very constitution of the term, the psychosocial perspective presupposes the combination of the relationships that the individual maintains with society and with the development of his/her psyche; it covers issues ranging from emotional support, the physical and mental health of those 
affected to social support, which includes aspects of material, health, spiritual and symbolic support ${ }^{13}$. Therefore, in addition to the conjuncture related to climate change, understanding and broadening the discussions on psychosocial aspects in the context of a disaster is essential, since the psychosocial consequences resulting from a disaster go beyond physical and emotional injuries and material and human losses. However, actions with this purpose remain on the fringe of attention due to the violent break from the routine that a disaster brings.

When analyzing the most countries affected by climate disasters in the last 20 years, it can be seen that the countries of the American continent are not the ones that suffer the most from these impacts. However, Brazil appears in the list of the $\mathbf{1 0}$ countries most affected by socio-environmental disasters in absolute numbers (51 million people) ${ }^{2}$. This data is mentioned in the report 'The Human Cost of WeatherRelated Disasters 1995-2015', published in 2015 by the United Nations Office for Disaster Reduction (UNISDR) and the Centre for Research on the Epidemiology of Disasters (Cred). The publication was based on Cred's emergency events database, the Emergency Events Database (EM-DAT), which gathers global information on the occurrence of disasters related to natural and technological events and their effects, since $1900^{2}$.

Given the situation presented, it is imperative to discuss the psychosocial aspects in these scenarios. Bringing the discussion to the context of South America and considering the different socio-political and economic realities of these countries, the objective of this review is to answer the following question: how psychosocial aspects have been explored in the scientific literature in the last 20 years (1997-2016) by authors and journals from countries in South America, in contexts of socio-environmental disaster of geoclimatic origin?
This way, it intends to contribute to the scientific knowledge about disasters by presenting the contextual and practical scenario of this part of the globe and its strategies to minimize the impacts on the health of populations in these events.

\section{Socio-environmental disasters of geoclimatic origin}

It is important to clarify what is being called in this article 'socio-environmental disasters of geoclimatic origin'. First, it was based on the view that a physical phenomenon of environmental origin (climatological, geological, hydrological, meteorological or biological) is only a disaster when a vulnerable environment, in interaction with this phenomenon, has no response capacity, resulting in negative consequences. Thus, there must be a combination of a threat, vulnerable conditions and insufficient capacity to respond to this event ${ }^{\mathbf{1 0}, \mathbf{1 4}, 15}$.

The second aspect is the essentially social nature of the disaster. No doubt, every disaster is social, since it reflects the socioeconomic conditions, the forms of organization, the degradation of the ecosystems of the environment affected, as well as being the result of climate change as a function of the way society has been constructed ${ }^{\mathbf{1 4}-18}$. Therefore, the classification of disasters as being of socioenvironmental origin (linked to natural events) or technological (directly caused by man, such as dam breakage, inappropriate use of toxic and nuclear substances, etc) is understood. In this article, the focus is on socio-environmental disasters (from natural events) related exclusively to climate and geophysical aspects, that is, geoclimatic ones.

In general, disasters triggered by 'natural' phenomena are classified as climatological (drought, dry season, forest fires), hydrological (inundations, overflows and floods), 
meteorological (cyclones, tornadoes, heat waves), geological or geophysical (landslides, erosion and earthquakes) or biological (epidemics, infestations and pests) ${ }^{\mathbf{1 9}}$.

The option to include geophysical events in the analysis of this review took into account the relationship between this type of event and climate change, given that studies have identified the association between global warming and geological risks, such as earthquakes and volcanic eruptions, showing the influence of high temperatures on the planet and the consequent pressure on the earth's crust in the occurrence of tectonic plate displacement $t^{6,20-23}$.

As hermeneutic-epistemological delimitation, it was chosen to qualify as 'geoclimatic disasters' all of climatological, hydrological, meteorological and geological origin, not including those of biological origin, as the epidemics for example.

\section{Material and methods}

It is an integrative review study, carried out by means of bibliographic survey in indexed databases. The survey took place in 2017, in which the following electronic bases were chosen: Coordination for the Improvement of Higher Education Personnel (Capes), Scientific Electronic Library Online (SciELO) and Regional Cooperative Online Information System for Scholarly Journals from Latin America, the Caribbean, Spain and Portugal (Latindex), in addition to the Regional Portal of the Virtual Health Library (VHL). The VHL was chosen for concentrating technical and scientific information on health in Latin America and the Caribbean, for bringing together the specialized center of the Pan American Health Organization (Paho)/WHO for scientific health information - Bireme (Latin American and Caribbean Center on Health Sciences Information) - and for including the Latin American and Caribbean Health Sciences Literature (Lilacs), Medline and a specialized disaster database.
Initially, the following types of publication were adopted as inclusion criteria (phase 1 of the bibliographic search): scientific articles, dissertations, theses and manuals that addressed psychosocial aspects in disasters in the Americas, from January 1997 to December 2016. The reasons for this more general search in this initial moment will be explained further in this topic. Another inclusion criterion adopted was that the materials were in Portuguese, English and/or Spanish and published in the aforementioned period. Exclusion criteria were texts with a focus on animal health in disasters (veterinary medicine, zootechnics, etc.) and publications whose abstracts were not available for access.

Descriptors listed in the DeCS (Health Sciences Descriptors) were used that understood the aspects related to the impacts, interventions and psychosocial support in disasters, and research was carried out in the DeCS to survey all the terms used in the bases that explored these three dimensions. The following descriptors were used: 'disasters', 'psychosocial impact', 'psychosocial support', 'social support', 'mental health', 'emergency response capacity,' 'disaster health effects', 'disaster planning', 'disaster relief', 'Rescue, Assistance and Protection in Disaster', 'disaster reconstruction' and 'post-disaster recovery'. Combinations were made between these terms in Portuguese and English, using the Boolean operator AND.

In this first phase, a broad bibliographic search was made, covering all types of disasters (not only those related to the climate) and throughout the American continent. The 'mining' of publications that dealt with climatic disasters and that were from South American periodicals and/or authors was carried out later, in a second phase (detailed in figure 1). This is explained because the initial intention was to know the global situation in disaster situations in the Americas. However, due to the large number of publications raised, it was decided to restrict the scope of analysis and, therefore, the objective of this review. 
The second search phase, in which a second filter was applied, aimed at gathering only publications that discussed geoclimatic disasters and periodicals and/or authors from South American countries (publications that did not necessarily discuss disasters in South
American countries). The intention was to find out what South American authors and periodicals had published in the period on the subject. This bibliographic survey went through three phases, detailed in figure 1.

Figure 1. Detailing the search process and literature selection criteria

Phase 1: definition of databases, descriptors and definition of inclusion and exclusion criteria
Databases: VHL Portal (Medline, Lilacs, Bireme),

SciELO, Capes and Latindex.

Descriptors: 'disasters', 'psychosocial impact', 'psychosocial support', 'social support', 'mental health', 'emergency response capacity', 'disaster health effects', 'disaster planning', 'disaster relief', 'Rescue, Assistance and Protection in Disasters', 'disaster reconstruction' and 'post-disaster recovery'.

Panorama of the Americas (journals and authors from the American continent) Period: 1997 to 2016

Texts in portuguese, english and spanish

$\mathrm{N}=1.072+380$ of the Latindex $=1.452$

Inclusion Criterion: scientific articles, theses, dissertations and manuals that addressed the psychosocial aspects in disasters. Publications from 1996 to 2016, in english, portuguese and/or spanish and that have been published by journals from countries in the American continent or by authors from those countries.

Exclusion Criterion: texts focusing on animal health in disasters (Veterinary Medicine, Zootechnics, etc.) and publications whose abstracts were not available for access.

Phase 2: publications filtering based on the new clipping (only publications that addressed socio-environmental disasters of geoclimatic origin, from South American periodicals and/or authors)

Phase 3: active search of full texts and abstracts
Out of the topic of disasters and psychosocial aspects, out of temporal cut, geography (outside South America) and repeated: $\mathrm{N}=1.190$ Unavailable: $\mathrm{N}=28$

They did not address geoclimatic disasters: $\mathrm{N}=167$

$\mathrm{N}=52$ (they address, directly or indirectly, the theme of psychosocial aspects in socio-environmental disasters of geoclimatic origin)

34 specifically address socio-environmental disasters of geoclimatic origin

18 punctually address socio-environmental disasters of geoclimate origin - generic texts, which address disasters in general, including geoclimate 
The initial search gathered 2.081 publications only on the Capes and SciELO databases and on the VHL portal; and after filtering repeated materials, outside the theme and time frame, it totaled 1.072 publications. At Latindex, it was not possible to define a more detailed cut like that carried out in the other indexed databases, given the scope limits of the platform itself. In this case, the term 'disasters' was used as a search word in the 'Directory' filter, one of the four databases offered by Latindex. This filter was chosen because it groups bibliographic data from all registered journals, both printed and electronic publications. The search at Latindex found three magazines related to disasters, however, only one of them identified materials that fell within the scope of the review: the journal Desastres y Sociedad (published by international organizations and associated with the Network for Social Studies on Disaster Prevention in Latin America, known as La Red, located in Panama).

The survey relied on Zotero, a bibliography management tool. It enabled the concentration in one place and the organization of all publications found in the searches, based on the descriptors used in each database and on the total of materials found. These were organized by thematic categories, typology, periodical, country and year of publication, nationality of the authors, objectives of publications and availability of access to materials. The publications were systematized by thematic categories, considering the dominant and secondary themes of the materials, the nationality of the author(s) and journals, year of publication and type of extreme event.

\section{Results and discussion}

The results indicated a production of 52 texts ${ }^{11,14,15,24-72}$, in the period of 20 years, by South American authors and/or journals, taking into account the criteria adopted in this review. This number corresponds to an average of 2.6 publications per year. Of the 34 specific productions on socio-environmental disasters of geoclimatic origin, 21 had as main theme earthquakes, but only those that occurred in Chile and Haiti in 2010. The productions on floods and inundations (7) and drought (6) also stood out, while drought-related ones were concentrated in 2016 (4).

The countries with the highest production were Brazil and Chile, as shown in graph 1: 
Graph 1. Distribution of South American publications from 1997 to 2016

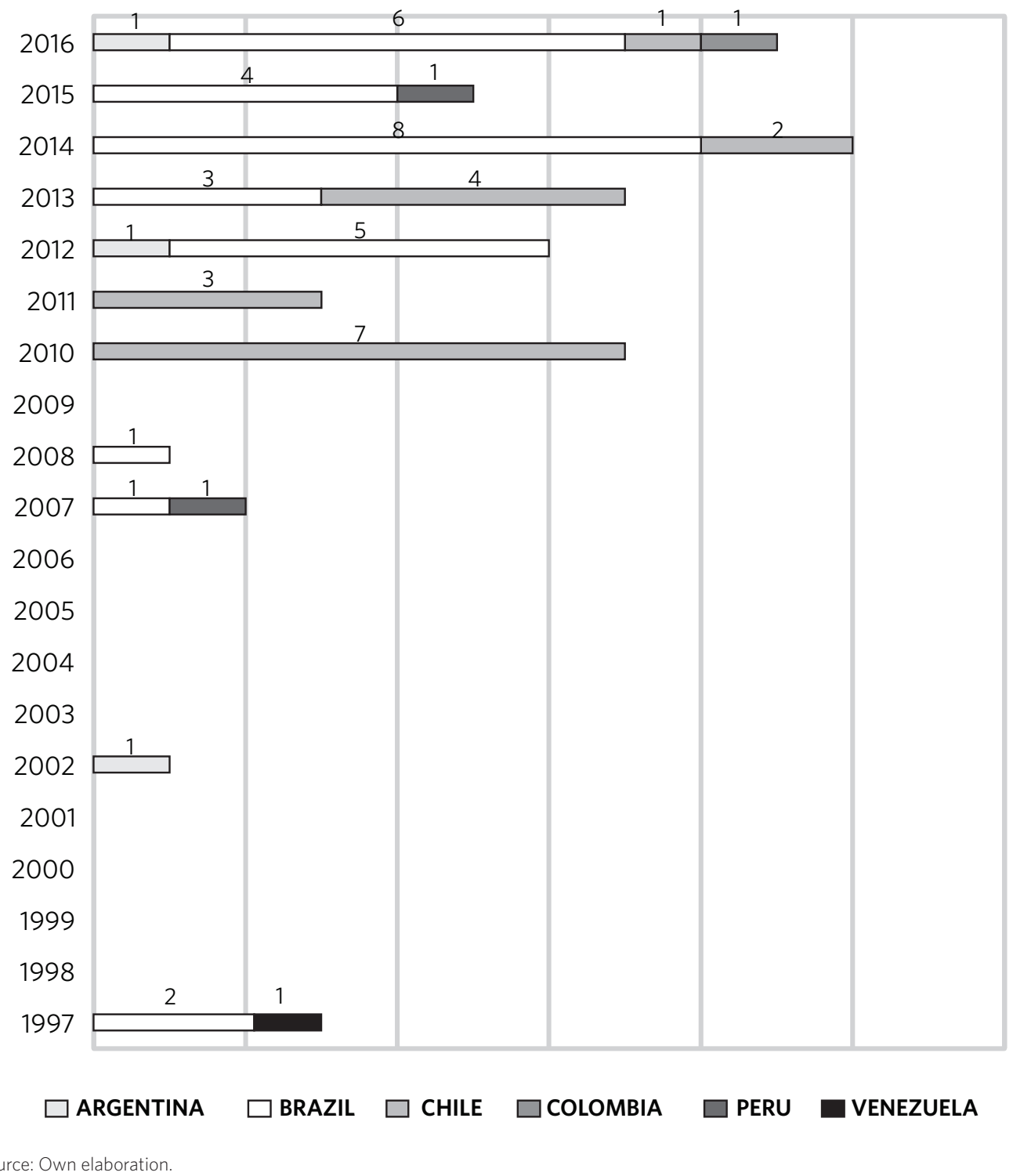

The results also indicated an increase in the number of publications by South American authors and/or journals from 2010, peaking in 2014 and with a gap between 1998 and 2001, 2003 to 2006 and 2009. In addition, the publications were concentrated in six countries of South America, of the 12 that integrate it:
Brazil, Chile, Argentina, Peru, Venezuela and Colombia.

Psychosocial aspects were addressed in publications based on four main themes: 'mental health', 'psychosocial and health impacts', 'public health' and 'risk management', as shown in chart 1 : 
Chart 1. Most discussed topics in the publications and discussions addressed

\begin{tabular}{|c|c|}
\hline Topic & Approaches \\
\hline $\begin{array}{l}\text { Mental health }(31)^{\mathbf{1 5}, \mathbf{2 4}-} \\
\mathbf{4 4 , 5 2 , 5 5 , 6 3 , 6 4 , 6 6 - 6 8 , 7 1 , 7 2}\end{array}$ & $\begin{array}{l}\text { - Psychopathological disorders (symptomatology of PTSD - Post-traumatic Stress } \\
\text { Disorder, depression, anxiety, stress, adaptive disorders and Attention Deficit Hyper- } \\
\text { activity Disorder - ADHD); Intervention with survivors (emphasis on the disaster re- } \\
\text { sponse phase - crisis management); Intervention experiences in mental health after an } \\
\text { earthquake in Chile in } 2010 \text { (10); Importance of evaluating interventions as a prevention } \\
\text { strategy in the development of traumatic pathologies; Integrated efforts with other sec- } \\
\text { tors, articulated and contextualized. }\end{array}$ \\
\hline $\begin{array}{l}\text { Psychosocial and health } \\
\text { impacts }(38) \mathbf{1 1 1 4 , 1 5 , 2 4 , 2 6 , 2 9 -} \\
\mathbf{3 8 , 4 5 - 5 3 , 5 5 , 5 6 , 6 0 - 6 8 , 7 0 - 7 2}\end{array}$ & $\begin{array}{l}\text { - Climate change and effects on the population's health; Droughts, inundations and } \\
\text { floods generating malnutrition and impacts on mental and environmental health; PTSD, } \\
\text { post-traumatic and depressive disorders, psychosocial implications in rural dwellers of a } \\
\text { municipality in the Northeast; Socio-environmental vulnerability and vulnerable groups } \\
\text { (children, adolescents and the elderly) and social abandonment. }\end{array}$ \\
\hline $\begin{array}{l}\text { Public health (19) })^{11,24-} \\
\mathbf{2 6 , 2 8 , 2 9 , 3 2 , 3 7 , 4 0 , 4 1 , 4 5 , 5 1 - 5 5 , 5 9 , 6 2 , 6 5}\end{array}$ & $\begin{array}{l}\text { - Association between the impacts of disasters on public health (case studies from the } \\
\text { states of Santa Catarina in } 2008 \text { and Pernambuco in 2010, drought, floods, earthquake } \\
\text { and tsunami in Chile in 2010, floods and landslides in Nova Friburgo in 2011); Relationship } \\
\text { between drought and health in Brazil, causing malnutrition, impacts on mental health, } \\
\text { water and air quality, access to health services; Health risks in mass events and disasters; } \\
\text { Biosafety; Response of the health system and international cooperation in the February } \\
2010 \text { earthquake and tsunami in Chile; Coordination and organization required within } \\
\text { health systems. }\end{array}$ \\
\hline $\begin{array}{l}\text { Risk management } \\
(13) \mathbf{1 4 , 1 5 , 4 8 , 4 9 , 5 1 , 5 3 , 5 5 -} \\
\mathbf{5 7 , 6 2 , 6 9 , 7 0 , 7 2}\end{array}$ & $\begin{array}{l}\text { - Risk analysis as a corrective and preventive measure, risk perception (risk ranking as } \\
\text { part of the understanding of risk perception); Civil defense; Analysis of socio-environ- } \\
\text { mental vulnerability and vulnerable groups (socio-environmental vulnerability creating } \\
\text { conditions for disasters and limiting prevention and mitigation strategies); Biosafety } \\
\text { (corpse management, inefficient public policies, environmental degradation, vulnerabili- } \\
\text { ty, climate change); Drought, dry season, floods and earthquake in Haiti in 2010; Climate } \\
\text { change, sustainable development agenda, Rio + 20; Risk associated with lower socioeco- } \\
\text { nomic development; Production of meanings (tensions between socio-environmental } \\
\text { disaster management and the importance of risk in everyday life); Characterization, } \\
\text { indicators and risk assessment in an integrated manner (human and biota); Risk commu- } \\
\text { nication technology as a preventive health practice. }\end{array}$ \\
\hline
\end{tabular}

Source: Own elaboration.

In the analyzed period (1997-2016), the year with the largest number of publications was 2014, with 10 productions. A fact that stood out in the results of that year was the focus of the productions having been the psychosocial impacts of disasters on populations, in studies on vulnerability and risk management.

The publications were systematized based on two structural thematic axes: 'psychosocial impacts' and 'psychosocial support', as shown in chart 2. 
Chart 2. Central key strands, focus of analysis identified in the most common publications and types of disasters (identified in brackets)

Psychosocial impacts on disasters
- Effects on health:
Communicable diseases (Floods), malnutrition (Drought), emotional insecurity, post-traumatic disorders, disorders
and symptoms of depression, stress and anxiety, suicide (in all types of disaster), psychological stress triggering chron-
ic cardiovascular diseases, aggressiveness;
- Social consequences:
Impairment of access and quality of basic services, problems in water and air quality, change in the social role in a
fragmented context (Drought and Floods), lack of assistance in post-impact, unhealthy temporary shelters, social in-
security, disbelief in the public power due to social abandonment in the process of reconstruction and recovery, socio-
environmental vulnerability, economic loss, increased poverty, loss of housing, gender violence, cases of opportunism in
international humanitarian aid (political interests);

- Symbolic consequences:

displacement of part of the family to obtain income due to the expropriation of affected lands - forced displacement, loss of family space (Drought, Floods, Volcanic Eruption).

\section{Psychosocial support in disasters}

Relief operations, emotional restraint, social support, emotional support workshops, evidence-based interventions, support at the biopsychosocial and behavioral levels, empowerment and community participation (protagonists in the reconstruction of daily life), strengthening of community resources, community therapy, training of professionals health and care, strengthening social capital, promoting networks of trust, strengthening family ties, preparing children and teachers for disaster risk, educational activities, strengthening values such as trust, solidarity and support, psychological first aid, systematization and evaluation of emotional support interventions, early and effective interventions to increase individuals' resilience and emotional strength, physical and mental care, psychological support to reduce psychological distress and help with physical rehabilitation sica, psychosocial interventions from a gender perspective, care spaces, community spaces, exploratory intervention maps, training and self-care with health professionals, coping strategies and psychosocial interventions in training with primary care professionals (focus on additional skills), primary care as a gateway to the health system, comprehensive care, psychoeducation, educational activities in general, shared and articulated work with other social sectors, psychological intervention in the online context, reframing the experience of the elderly, spiritual faith, integrative systemic therapy.

Source: Own elaboration.

As for the methodologies used in the publications, 21 were qualitative researches ${ }^{\mathbf{1 4}, 26,27,32,34,35,38,39,42,46,49,52,54,55,57-59,61,65,70,71}$ (with emphasis on two studies of participatory intervention 35,71$)$; 13 , quantitative $\mathbf{2 5 , 2 9 - 3 1 , 3 7 , 4 7 , 4 8 , 5 0 , 6 0 , 6 2 , 6 6 - 6 9 , ~ l i t e r a t u r e ~}$ reviews ${ }^{11,15,24,28,36,40,43-45,51,53,56,63,64,72}$ (two being systematic $\left.{ }^{28,51}\right)$; and three studies of qualitative and quantitative nature $33,41,60$.

The period analyzed in this review was marked by important strategic milestones with regard to disaster risk reduction in the world. We can mention, initially, the International Strategy for Disaster Reduction (Eird/ISDR), adopted in 2000 by UN member states. The intention was to reduce the losses generated by disasters and to build resilient communities and countries to face these events. The purpose was to systematize actions by each country, based on national platforms for disaster risk reduction ${ }^{63}$. In addition to the International Strategy, we can mention the Hyogo Framework for Action ${ }^{73}$ (which established goals to be achieved by the year 2015) and the Sendai Framework for Action $\mathbf{7 4}$ (a complement to the Hyogo Framework, with actions defined in 2015 and cut-off date of 2030).

The Hyogo Framework was agreed between 168 countries in 2005 with a commitment to develop disaster risk reduction measures. Its strategic objective was to achieve, by the year 
2015, disaster risk reduction and increase community and nation resilience ${ }^{73}$. Therefore, the concentration of publications from the time frame of this review in 2014 can be explained by the influence of the Hyogo Framework. About to reach the limit year of the target established to achieve the goals of disaster risk reduction of the landmark (2015), many productions were dedicated, in 2014, to the impacts caused by disasters, in the disaster response phase and in the issue of vulnerability (vulnerable groups and environments).

The five phases of Disaster Risk Management (DRM) described in the National Policy on Protection and Civil Defense ${ }^{75}$ were considered in the systematization of this article: prevention, preparedness, mitigation, response and recovery.

The years 2013, 2016 and 2010 had the second largest number of publications, with seven materials each. The 2016 productions are believed to have reflected the influence of discussions from another milestone, that of Sendai, adopted in 2015 by UN member states. Undoubtedly, this important instrument, which complemented the Hyogo Framework, mobilized the scientific community to act in order to reduce risks and expand the perspectives of analysis. It is noteworthy that one of the key aspects of the Sendai Framework was the shift in focus from disaster reduction to disaster risk reduction. Thus, the number of publications in 2016 reflects, in a way, the concern with climate change and the post2015 development agenda.

With regard to the significant number of materials on drought in 2016, it is important to highlight the El Niño phenomenon across the globe. Many reports dealing with the climate on the planet point out that 2015 was an extremely dry year. In South America, for example, despite the fact that many countries in the subtropical strip have experienced humid weather in 2015, Brazil appears to have been greatly affected by drought, with the exception of the Southeast ${ }^{6}$.

The predominance of discussions on the prevention and response phases in disasters and the little debate on the recovery/reconstruction phase, which appears in only seven publications ${ }^{26,30,53,58,61,63,65}$, highlight the need not only for more publications in the area, but, above all, the strong tendency to focus on the prompt response in these contexts, revealing the adoption of specific strategies and which in many cases do not consider the long-term impacts on the different dimensions of the subjects. When explored, the recovery phase is associated with the performance of the mental health field and the impacts of late and/or punctual intervention on psychological health in the long term, which can lead to cases of Post-Traumatic Stress Disorder (PTSD) and depression.

Another aspect observed was the absence of the term 'psychosocial' in 13 publica-

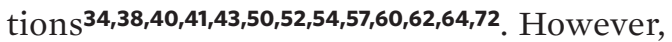
even without using the term, they portrayed the psychological and social dimensions together, from the perspective of the impacts on these dimensions $\mathbf{3}^{34,50,52,54,57,60,62,64,72}$ and to talk about the social and psychological support to those affected ${ }^{38,40,41,43}$.

\section{Psychosocial and health impacts}

Thirty-eight publications explored, to some extent, the impacts of disasters on the psychosocial dimension and health, as well as the use of psychosocial resources in coping with the disaster 11,14,15,24,26,29-38,45-53,55,56,60-68,70-72. Social, environmental, individual, structural or institutional vulnerability was discussed in 11 publications $\mathbf{1 4 , 1 5 , 2 4 , 2 6 , 4 5 , 4 6 , 4 9 , 5 0 , 5 6 , 7 0 , 7 2}$. Vulnerable groups, such as the elderly, children and adolescents, were highlighted in seven of them $32,33,35,46,66-68$, in which the authors spoke of the importance of psychoeducation in preventing preventable damage on a social and emotional level. Three of these studies reported the prevalence of PTSD in children and teachers after the 2010 earthquake in Chile66-68. They explained that psychoeducation, family strengthening and 
social cohesion strategies have an effective role in reducing psychosocial impacts in these vulnerable groups. They exposed the impacts of PTSD on the development of affected children, with the risk of presenting other pathologies in the long term ${ }^{33,66-68}$, and the need to implement preventive programs for the young population affected by disasters. One of the studies showed that policies with a high impact in coping with disasters over the years in Chile have been adapting to the Country's socio-epidemiological reality and that the mental health of children has been gaining relevance ${ }^{32}$. The study on Chilean older adults, on the other hand, dealt with the redefinition of networks and life itself, indicating that this should also be a group worthy of attention in disaster planning ${ }^{46}$. An interesting aspect of some publications dealing with impacts was the positive outlook for the disaster. Some studies have defined these potentially traumatic experiences as enriching, alluding to positive psychology and the concepts of resilience and post-traumatic growth. These concepts defend learning and positive changes in the face of negative situations and are considered a way of adapting to potentially traumatic situations. They claim that there is a component capable of bringing growth in these contexts, and that it should be explored ${ }^{32,63,72}$. In some studies, the overlapping of vulnerabilities and impacts has also been investigated as a result of social abandonment in the recovery and reconstruction process $^{\mathbf{1 4 , 2 6} \text {. }}$

\section{Mental health}

Thirty-one publications portrayed the psychosocial aspects from the perspective of mental health $15,24-44,52,55,63,64,66-68,71,72$. They spoke of the importance of early psychosocial interventions (in the first hours that follow the day of the event) so that there are no long-term impacts on mental health, especially cases of PTSD and depression $^{11,24,26,27,30,35,37,39,40}$. Studies mentioned that early intervention works to recover the psychosocial resources of those affected ${ }^{64}$, that psychosocial support ${ }^{27,29}$, mental and spiritual support to victims, family members and health professionals should be included in the action plans ${ }^{51}$ and that greater exposure in disasters leads to greater chances of developing PTSD and clinically significant disorders in the long term $26,52,55,67$. A fact that drew attention was the paradigm shift regarding the concept of trauma, as some studies in this review (one of them based on systematic reviews and meta-analyzes ${ }^{40}$ ) demonstrated the need for early and continuous psychological intervention, taking into account several sectors and disciplinary fields ${ }^{30,63,68,40}$ and the importance of understanding that a portion of those affected by a disaster will not necessarily present post-traumatic mental disorder.

Thus, there is a shift from a pathological and drug view to an approach that values psychosocial aspects and confrontation. The first psychological care, psychoeducation, psychological screening in the first days after the event, the coordinated work with the local public health network and joint work with social workers and humanitarian assistance professionals are some examples of actions that reduce the risks of development of post-traumatic illnesses. In this sense, it is possible to highlight the criticism made, in one of the publications, to the focus given to mental health problems in public health over the years, which proves that there has been an evolution in the approach, giving rise to discussions that privilege actions psychosocial, prevention and mitigation of the consequences of the disaster on health, and not only mental disorders ${ }^{36}$.

The perspective of positive psychology present in some publications $\mathbf{1 5 , 3 2 , 4 4 , 6 3 , 6 6 , 7 2}$ brings the idea of disaster as an event that enables growth and mobilizes coping resources. The concepts of resilience and posttraumatic growth explained, for example, the growth of public policies and the strengthening of national identity in Chile after the 
2010 earthquake according to one of the studies $^{32}$. The disaster was evaluated as an opportunity for growth for the Country, marked by countless earthquakes in its history. In addition to these aspects, in some studies, the strategic role of public health centers in the emotional monitoring of those affected was mentioned, which offer people the first psychological care, security, care, social support, information and facilitate the return to their routine activities. These resources are seen as risk moderators for the development of possible pathologies $\mathbf{4 0}^{\mathbf{4}}$.

Social support is mentioned as a relevant psychosocial factor and generates greater satisfaction in the lives of those affected, impacting their mental health ${ }^{25}$. Along these lines, one of the studies identified the correlation between a low level of social support and the increase in psychological suffering, indicating that, in Latin American culture, some of the central elements of its identity are collectivism, social cohesion and solidarity, compared to individualistic cultures ${ }^{72}$. Psychosocial support was addressed with a perspective not only of reducing psychological distress, but also of physical rehabilitation ${ }^{30}$.

\section{Public health}

Public health was investigated in 19 publications $11,24-26,28,29,32,37,40,41,45,51-55,59,62,65$, focusing on health risk ${ }^{11,40,41,49,53}$, the importance of mutual support between the different bodies that make up the health sector of a country ${ }^{11,32,37,40,41,51}$, the impacts on health and organization of the sector in these scenarios ${ }^{11,24,26,28,32,37,40,41,45,52-55,62}$, in community participation as a basis for psychosocial intervention $\mathbf{2 4 , 4 1 , 5 2 , 5 9 , 6 5}$, in primary health care as a strategic element $\mathbf{2 5 , 2 9 , 4 0 , 5 4 , 5 9 , 6 5}$, and the importance of defining, in the first stages of the response phase, the psychosocial processes demanded in disasters to support victims, families and professionals involved $11,26,40,51,53,54$. Some studies have demonstrated data indicating that increased exposure to the impacts of a disaster leads to clinically significant disorders in the long run ${ }^{26,52,55}$, which reinforces the need for the health sector to be attentive to reducing these impacts and risks in all phases of the disaster. Continuous and long-term monitoring of the effects of the disaster on health was also recommended"1, as well as the use of psychosocial intervention practices that have shown effective results in public health, such as community therapy in the Brazilian Unified Health System (SUS) ${ }^{\mathbf{5 9}}$ and the positive experiences of the Family Health model in Chile ${ }^{54}$ and Brazil ${ }^{65}$. One of the approaches given to health risk was discussed from the perspective of public health in the publication on biosafety and body management, associating the importance and speed of this service with the reduction of the psychological burden of survivors ${ }^{53}$.

\section{Risk management}

Thirteen publications dealt with risk management (risk analysis, perception and communication) $\mathbf{1 4 , 1 5 , 4 8 , 4 9 , 5 1 , 5 3 , 5 5 - 5 7 , 6 2 , 6 9 , 7 0 , 7 2}$, with a greater analysis focus on vulnerability and analysis risk management as a preventive practice. An example of this was a review carried out by Chilean authors on the perception of risks and socio-environmental disasters of a potentially vulnerable population in Chile ${ }^{72}$, in which they pointed out the importance of obtaining information on the perception of risk for the formulation of educational campaigns for disaster prevention, showing that the cultural component also crosses the way we face them. They made an interesting distinction about individualist and collectivist cultures, citing Anglo-Saxon culture as an example of individualism and Latin American culture as a collectivist, with a greater predominance of cultural cohesion and solidarity ${ }^{\mathbf{2}}$.

Still on risk management, the productions of the countries of South America reflect how they have managed disasters: risk perception is still discussed while the tonic in other parts 
of the globe is much more advanced. This reinforces the urgent need for educational policies, especially in Brazil.

In this sense, the lack of concern with the different dimensions of social suffering of groups affected by disasters was identified as a negative point in a study that evaluated the institutional purpose of Civil Defense in Brazil. Its technical aspect was criticized, which ends up not encompassing important dimensions, such as impacts in the recovery phase and vulnerabilities prior to the event ${ }^{14}$.

In Chile, a study carried out to assess mental health activities conducted by primary health care centers in Maule, a region affected by the 2010 earthquake and tsunami, indicated that there was difficulty in dealing with the mental health problems triggered by the disaster and that the failure to identify previous vulnerabilities in the location interfered with the effectiveness of the assistance. The lack of coordination, planning and local exercises also emerged as a problem for the effectiveness of actions ${ }^{29}$.

\section{Climate change and sustainable development policies}

Only five articles in the review referred to climate change, the post-2015 global political agenda and policies based on sustainable

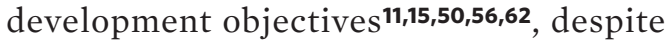
the strategies already mentioned. It is a low number when considering the global importance of this theme as a transversal axis of policies. Drought was the central theme of analysis in three of these publications, sometimes relating it to risks, hazards and disasters, now exploring the reality of the Brazilian Northeastern semi-arid and the tendency to increase water scarcity by 2030 and its impact on health public. An article discussed the floods"1, which were also analyzed in relation to their effects on public health. The five articles are by Brazilian authors and journals.

\section{Social capital and social participation as strategies for strengthening and resilience}

Social capital is defined as the ability of a community or group to form different types of associations, formal or informal, allowing the interrelation and collaboration of its participants based on the principles of mutual trust, reciprocity and cooperation ${ }^{60}$. In one of the studies carried out after the 2010 earthquake in Chile, the authors signaled, using empirical data, that when the initial social capital of a community is extremely low, the increase in community confidence after the disaster is smaller. In addition, they emphasized that low social capital influences the impacts of the disaster, which increase in the medium and long term, and also favors violence in the post-disaster ${ }^{60}$.

Social empowerment was also portrayed from the perspective of adaptation strategies, showing the effect of spiritual faith as a mediator of anguish linked to poverty, the latter as a psychosocial dimension. An analysis of the relationship between psychosocial well-being and extreme poverty was carried out, showing the reality of a favela in the city of Fortaleza (CE), in which a high degree of perception of well-being and psychosocial aspects causing it was identified of anxiety. The authors identified interventions with systematic integrative therapy and the use of spiritual faith as 'anchors of emotional stability and well-being' and showed that there is fragmentation in scientific approaches to the psychosocial consequences of disasters in groups in situations of poverty and extreme poverty. They indicated the model of systematic integrative therapy as a valuable 'anxiety modifier' related to disasters and poverty ${ }^{\mathbf{7 1}}$.

Regarding the disaster in the mountainous region of the state of Rio de Janeiro, triggered by heavy rains and landslides in January 2011, the survey revealed a gap in production that investigated this emblematic disaster that occurred in Brazil: only four ${ }^{11,15,27,48}$. It is worth 
noting that this disaster was classified by the $\mathrm{UN}$ as the 8th largest landslide occurring on the planet in the last 100 years, having been compared to Hurricane Katrina of 2005 when it comes to damage and magnitude ${ }^{\mathbf{2}}$. Given the relevance of this event for the country, which highlighted social inequality and the socioeconomic and spatial vulnerability of the places where there were land displacements, the scientific community should have looked at the psychosocial initiatives carried out in the affected places. This sharing of experiences is essential for the multiplication of successful practices and is important because it represents evidence-based practices.

\section{Final considerations}

In order to contribute to scientific knowledge about disasters, this integrative review sought to answer 'how psychosocial aspects have been explored in the scientific literature in the last 20 years (1997-2016) by authors and journals from countries in South America, in contexts of socio-environmental disaster of geoclimatic origin'. Considering the importance of psychosocial aspects in the context of disasters and their role in action planning, it enabled an overview of South American production in the analyzed period, the different perspectives on psychosocial aspects in disasters, strategies and approaches used.

What has been observed is the need to leave, particularly in Brazil, a culture of disaster risk, which focuses on triggering events, to give rise to a culture of confronting risks from its structural causes, such as spatial vulnerability and specific groups. The focus on the externalities of the causes of disasters, that is, on the physical events of nature, becomes a dangerous way of trying to understand them and limits mitigation and prevention actions. There is an attribution of the disaster to threatening physical events, and not to the current social processes and the inappropriate use of the territory.
However, the publications collected in this review demonstrated the concern of the South American scientific community with structural causes, which are increasingly related to social inequalities and socio-environmental vulnerabilities. According to the studies, South American countries need to channel their efforts towards building resilient communities and minimizing structural and social, political and economic problems, such as reducing inequalities and social vulnerability, which are known to enhance of disasters. However, what we see, unfortunately, is a production that is not effective in practice; actions that are conditioned to political decisions and interests, which undermine efforts to reduce disaster risks.

It can be seen that Chile's reality, after the emblematic earthquake and tsunami of February 2010 and other similar events in its territory, 'shaped', as stated in one of the articles, the construction of identity and public policies in that country, where Disaster risk management processes have been built over the years based on prevention, adaptation to coping and psychosocial strategies based on prevention, response and recovery, especially in the screening and monitoring of psychopathological symptoms. However, due to a lack of coordination with other sectors and coordination and planning, in some contexts, the population was unassisted and had insufficient mental health coverage.

Finally, it is emphasized that, despite the 'psychosocial' descriptor and the keywords contained in the materials, most of the publications dealt exclusively with psychological support and/or impacts, neglecting other elements that the psychosocial dimension encompasses. Thus, this review draws attention to the fact that most publications containing the term 'psychosocial' still prioritize psychological aspects, showing a strong tendency to focus on the field of mental health during the analysis of 'psychosocial' aspects in disasters. However, the non-recognition of the various dimensions of the psychosocial scope in disasters 
can generate overlapping damage and act as a generator of other disasters.

\section{Acknowledgements}

Financial support received from the Coordination for the Improvement of Higher Education Personnel - Brazil (Capes) and the Carlos Chagas Filho Research Support Foundation in the State of Rio de Janeiro (Faperj).

\section{References}

1. Organizações das Nações Unidas Brasil. ONU: $90 \%$ das mortes devido a desastres acontecem em países de renda baixa e média. [internet]. 27 de outubro de 2016 [acesso em 2017 out 10]. Disponível em: https://nacoesunidas.org/onu-90-das-mortes-devido-a-desastres-acontecem-em-paises-de-renda-baixa-e-media/.

2. Centre for Research on the Epidemiology of Disasters; The United Nations Office for Disaster Rick Reduction. The human cost of weather-related disasters 1995-2015 [internet]. 2015. [acesso em 2018 maio 15]. Disponível em: https://www.unisdr.org/files/46796_ cop21weatherdisastersreport2015.pdf.

3. Organizações das Nações Unidas. The United Nations Office for Disaster Rick Reduction. Poverty and Death: Disaster Mortality 1996-2015 [internet]. [acesso em 2018 nov 4]. Disponível em: https://www.unisdr. org/we/inform/publications/50589.

\section{Collaborators}

Carvalho MM (0000-0002-0433-0838)* contributed to the conception, planning, analysis and data interpretation, elaboration of the draft, critical review of the content and approval of the final version of the manuscript. Oliveira SS (0000-0001-5477-6216)* contributed to the conception, planning, critical review of the content and approval of the final version of the manuscript
*Orcid (Open Researcher and Contributor ID).
4. Banco Mundial. Avaliação de perdas e danos: inundações e deslizamentos na Região Serrana do Rio de janeiro - janeiro de 2011. Relatório elaborado pelo Banco Mundial com apoio do Governo do Estado do Rio de Janeiro. Brasília, DF: Banco Mundial; 2012.

5. Brasil. Ministério da Saúde; Organização Pan-Americana da Saúde. Mudanças climáticas e ambientais e seus efeitos na saúde: cenários e incertezas para o Brasil. Brasília, DF: Organização Pan-Americana da Saúde; 2008.

6. World Meteorological Organization. The Global climate in 2013-2015, $\mathrm{N}^{\circ} .1179$ [internet]. 2016. [acesso em 2018 nov 16]. Disponível em: http://www.observatoriodoclima.eco.br/onu-liga-eventos-extremos-a-aquecimento/.

7. Field CB, Barros V, Stocker TF, et al., editores. IPCC 
2012: Managing the Risks of Extreme Events and Disasters to Advance Climate Change adaptation. A Special Report of Working Groups I and II of the Intergovernmental Panel on Climate Change. Cambridge: Cambridge University Press; 2012.

8. Pachauri RK. Reflections on COP 15. [internet]. 2010. [acesso em 2018 nov 18]. Disponível em: http:// www.fasid.or.jp/daigakuin/sien/kaisetsu/ doc_pdf/100108report.pdf.

9. Haines A, Kovats RS, Campbell-Lendrum D, et al. Climate change and human health: impacts, vulnerability and public health. Public Health. 2006; 120(7):585596.

10. Mata-Lima H, Alvino-Borba A, Pinheiro A, et al. Impactos dos desastres naturais nos sistemas ambiental e socioeconômico: o que faz a diferença? [internet]. Ambient. soc. 2013 [acesso em 2018 set 16]; 16(3):4564. Disponível em: https://www.scielo.br/pdf/asoc/ v16n3/v16n3a04.pdf.

11. Freitas CM, Ximenes EF. Enchentes e saúde pública: uma questão na literatura científica recente das causas, consequências e respostas para prevenção e mitigação. Ciênc. Saúde Colet. 2012; 17(6):1601-1616.

12. World Meteorological Organization. WMO. The Global Climate 2011-2015. [internet]. [acesso em 2018 abr 12]. Disponível em: https://public.wmo.int/en/ media/press-release/global-climate-2011-2015-hot-and-wild.

13. Alves ES, Francisco AL. Ação psicológica em saúde mental: uma abordagem psicossocial. Psicol. Ciênc. Profissão. 2009; 29(4):768-779.

14. Valencio NFLS. Disasters: technicism and social suffering. 2014; 19(9):3631-44.

15. Freitas CM, Carvalho ML, Ximenes EF, et al. Socio-environmental vulnerability, disaster risk-reduction and resilience-building: lessons from the earthquake in Haiti and torrential rains in the mountain range close to Rio de Janeiro in Brazil. Ciênc. Saúde Colet. [internet]. 2012; 17(6):1577-86.
16. World Bank \& United Nations. Natural hazards, unnatural disasters: the economics of effective prevention. Washington, DC: The International Bank for Reconstruction and Development; The World Bank; 2010.

17. United Nations Conference on Sustainable Development. Disaster-resilient Societies - Facts and figures. [internet]. 2012 [acesso em $2019 \mathrm{dez} 12$ ]. Disponível em: http://www.un.org/en/sustainablefuture/ disasters.shtml.

18. Narváez L, Lavell A, Ortega GP. La gestión del riesgo de desastres: un enfoque basado en procesos. San Isidro: Secretaría General de la Comunidad Andina; 2009.

19. Brasil. Ministério da Saúde. Desastres de origem natural [internet]. [acesso em 2018 out 26]. Disponível em: http://portalms.saude.gov.br/vigilancia-em-saude/vigilancia-ambiental/vigidesastres/desastres-de-origem-natural.

20. The Guardian. How climate change triggers earthquakes, tsunamis and volcanoes [internet]. 2016 out 16. The Guardian. [acesso em 2019 fev 10]. Disponível em: https://www.theguardian.com/world/2016/ oct/16/climate-change-triggers-earthquakes-tsunamis-volcanoes.

21. Liu C, Linde AT, Sacks IS. Slow earthquakes triggered by typhoons. Nature. 2009 [acesso em 2020 maio 7]; (459):833-836. Disponível em: https://doi. org/10.1038/nature08042.

22. Mcguire WJ. Waking the giant: how a changing climate triggers earthquakes, tsunamis, and volcanoes. Oxford: University Press; 2012.

23. Viterito A. The correlation of seismic activity and recent global warming. J earth sci clim change. 2016; (7):345.

24. Abeldaño RA, Fernández R. Salud mental en la comunidad en situaciones de desastre. Una revisión de los modelos de abordaje en la comunidad. Ciênc. Saúde Colet. 2016; 21(2):431-42. 
25. Portugal FB. Quality of life of primary care patients in Rio de Janeiro and São Paulo, Brasil: associations with stressful life events and mental health. 2016; 21(2):497-508.

26. Londe LR, Marchezini V, Conceição RS, et al. Impactos de desastres socioambientais em saúde pública: estudos dos casos dos estados de Santa Catarina em 2008 e Pernambuco em 2010. Rev bras estud popul. 2015; 32(3):537-62.

27. Weintraub ACA, Knobloch F, Vicente LN, et al. Atuação do psicólogo em situações de desastre: reflexões a partir da práxis. Interface comum. saúde educ. 2015; 19(53):287-98.

28. Silva JAM, Siegmund G, Bredemeier J. Crisis interventions in online psychological counseling. Trends in psyc. psychot. 2015; 37(4):171-82.

29. Vitriol V, Minoletti A, Alvarado R, et al. Respuesta de los centros de atención primaria en salud mental después del terremoto y tsunami del 2010 en la región del Maule. Rev med chil. 2014; 142(9):1120-7.

30. Guimaro MS, Steinman M, Kernkraut AM, et al. Psychological distress in survivors of the 2010 Haiti earthquake. Einstein (São Paulo). 2013; 11(1):11-4.

31. Guimaro MS. Post-traumatic stress disorder symptoms among professionals during humanitarian aid in Haiti after the earthquake in 2010. Ciênc. Saúde Colet. 2013; 18(11):3175-81.

32. Schonhaut BL. Terremotos, solidaridad y movilización nacional. Rev chil pediatr. 2013; 84(1):20-5.

33. Sommer AK, Barreau VM, Dávila DA. et al. Intervención de salud mental en niños expuestos a desastre natural. Rev chil pediatr. 2013; 84(1):59-67.

34. Gomes ERB, Cavalcante ACS. Desastres naturais: perdas e reações psicológicas de vítimas de enchente em Teresina-PI. Psicol soc. 2012; 24(3):720-8.

35. Correa A, Abufhele M, Briceño AM, et al. Intervención de salud mental para niños expuestos al desas- tre en la comunidad de Iloca: experiencia de la unidad de psiquiatría infantil de clínica alemana. Rev soc psiquiatr neurol infanc adolesc. 2011; 22(1):92-101.

36. Cova F, Rincón P. El terremoto y tsunami del 27 -f y sus efectos en la salud mental. Ter psicol. 2010; 28(2):17985.

37. Erazo C, Pemjean A. Red de atención de salud mental en chile y el terremoto de febrero 2010: fortalezas, daños y respuestas. Rev chil salud pública. 2010; 14(1):59-65.

38. García FE, Mardones R. Prevención de trastorno de estrés postraumático en supervivientes del terremoto de Chile de febrero de 2010: una propuesta de intervención narrativa. Ter psicol. 2010; 28(1):85-93.

39. Méndez MD, Leiva MC, Bustos CB, et al. Mapa exploratorio de intervenciones psicosociales frente al terremoto del 27 de febrero de 2010 en la zona centro-sur de Chile. Ter psicol. 2010; 28(2):193-202.

40. Figueroa RA, González M, Marín H. Apoyo psicológico en desastres: propuesta de un modelo de atención basado en revisiones sistemáticas y metaanálisis. Rev med chil. 2010; 138(2):143-51.

41. Loubat M, Fernández AM, Morales M. La experiencia de peralillo: una intervención psicológica para el estado de emergencia. Ter psicol. 2010; 28(2):203-7.

42. Peru. Ministerio de Salud. Dirección regional de salud ICA. Cómo trabajar salud mental comunitaria en situaciones de emergencia: lineamientos del IASC sobre salud mental y apoyo psicosocial en emergencias humanitarias y desastres. Lima: MS; 2007.

43. Comité permanente entre organismos. Guía del IASC sobre salud mental y apoyo psicosocial en situaciones de emergencia. Versión resumida. Ginebra: IASC; 2007.

44. Guimarães LAM, Guimarães PM, Neves SNH, et al. A técnica de debriefing psicológico em acidentes e desastres. Mudanças. 2007; 15(1):1-12. 
45. Benyakar M. Salud mental y desastres: nuevos desafíos. Revista neurol. Neuroc. y psiquiatría. 2002; 35(1):3-25.

46. Alpino TA. Disasters related to droughts and public health - a review of the scientific literature. Ciênc. Saúde Colet. 2016; 21(3):809-20.

47. Díaz CA, Lamig MAV, Venegas MQ, et al. Re-signification of life experience in older adults affected by three kinds of natural disasters in Chile. FQS. 2016; 17(1):1-37.

48. Camurça CE, Alencar A, Cidade E, et al. Implicações psicossociais da seca na vida de moradores de um município da zona rural do nordeste do Brasil. Avanc. psicol. Latino-americana. 2016; 34(1):117-128.

49. Freitas CM, Silva DRX, Sena ARM, et al. Natural disasters and health: an analysis of the situation in Brazil. Ciênc. Saúde Colet. 2014; 19(9):3645.

50. Spink MJP. Viver em áreas de risco: tensões entre gestão de desastres ambientais e os sentidos de risco no cotidiano. Ciênc. Saúde Colet. 2014; 19(9):3743-54.

51. Xavier D, Barcellos C, Freitas C. Extreme weather events and their consequences on health: the 2008 disaster in Santa Catarina taking into account different information sources. Ambiet. soc. [internet]. 2014; 17(4):273-290.

52. Castro CF, Simoes DCM, Delamarque EV, et al. Mass events, disasters and public health/Eventos de massa, desastres e saúde pública. Ciênc. Saúde Colet. 2014; 19(9):3717.

53. Shoaf K. Organizing the health sector for response to disasters. Cad. Saúde Pública. 2014; 19(9):3705-15.

54. Cardoso TAO. Biosecurity and disaster: concepts, prevention, public health and management of corpses. Physis. 2012; 22(4):1523-42.

55. López TE, Santana NP. El terremoto de 2010 en chile: respuesta del sistema de salud y de la cooperación internacional. Rev panam salud pública. 2011; 30(2)160-6.
56. Grigoletto JC, Cabral AR, Bonfim CV, et al. Management of health sector actions in drought situations. Ciênc. Saúde Colet. 2016; 21(3):709.

57. Favero E, Diesel V. A seca enquanto um hazard e um desastre: uma revisão teórica. Aletheia. 2008; (27):198.

58. Bodstein AV. The vulnerability of the elderly in disasters: the need for an effective resilience policy. Ambient. Soc. 2014; 17(2):171-185.

59. Cueto RM, Fernández MZ, Moll S, et al. Community participation and strengthening in a reconstruction context after a natural disaster. J prev interv community. 2015; 43(4):291-303.

60. Santos Padilha C, Oliveira WF. Community therapy: practice reported by professionals within SUS in Santa Catarina, Brazil. Rev Gaúcha Enfer. 2012; 16(43):1069.

61. Dussaillant F, Guzmán E. Trust via disasters: the case of Chile's 2010 earthquake. Disasters. 2014; 38(4):80832 .

62. Magaña Frade I, Silva-Nadales S, Rovira Rubio R. Catástrofe, subjetividad femenina y reconstrucción: aportes y desafíos desde un enfoque de género para la intervención psicosocial en comunidades afectadas por el terremoto. Ter Psicol. 2010; 28(2):169-77.

63. Sena A, Barcellos C, Ramalho W, et al. Measuring the invisible: analysis of the sustainable development goals in relation to populations exposed to drought. Ciênc. Saúde Colet. 2016; 21(3):671-84.

64. Paranhos ME, Werlang BG. Psicologia nas emergências: uma nova prática a ser discutida. Psicol. cienc. prof. 2015; 35(2):557-71.

65. Rocha V, Freitas CM. The theme of disaster in health care: profile of technical and scientific production in the specialized database on disasters of the virtual health library - vhl. Ciênc. Saúde Colet. 2014; 19(9):3775-90.

66. Fernandes GCM, Boehs AE, Heidemann ITSB. O su- 
porte social durante a transição familiar no pós-desastre natural. Texto \& contexto - Enfermagem. 2013; 22(4):1098-105.

67. Cova F, Valdivia M, Rincón P, et al. Estrés postraumático en población infantojuvenil post $27 \mathrm{f}$. Post-traumatic stress disorder in young population after the natural disaster on february 27, 2010. Rev soc psiquiatr neurol infanc adolesc. 2011; 22(1):2-11.

68. Briceño AM, Abufhele M, Dávila AM, et al. Estrés postraumático en escolares a 8 meses del 27f. Post-traumatic stress disorder in children in a coastal town eight months after the earthquake/tsunami. Rev soc psiquiatr neurol infanc adolesc. 2011; 22(1):12-20.

69. Bedregal P, Carvallo C, Hernández V, et al. Estrés post-traumático post terremoto $27 \mathrm{f}$ en cuidadores principales de niños preescolares, factores asociados del cuidador, de la familia y la crianza. Post-traumatic stress disorder after 27/f earthquake in primary caregivers of preschool children, factors associated with the caregiver, family and parenting. Rev soc psiquiatr neurol infanc adolesc. 2011; 22(1):21-28.

70. Rojas MC, Meichtry NC, Vázquez JC, et al. El riesgo de la vivienda urbana para la salud de la población. Un análisis desde la salud colectiva y la vulnerabilidad social. 2012.

71. Panza R, Wiesenfeld E. Las tres caras de los desastres: percepción de riesgo, derrumbe y reubicación. Rev. Desast. socied. [internet]. 1997 [acesso em 2017 mar 15]; 5(8):76-90. Disponível em: https://www.desenredando.org/public/revistas/dys/.
72. Mocellin J, Barreto A, Gural D. Pobreza y desastres: terapia integrante sistemática en una barriada pobre de Brasil Rev. Desast. socied. [internet]. 1997 [acesso em 2017 mar 15]; 5(8):69-77. Disponível em: https:// www.desenredando.org/public/revistas/dys/.

73. Díaz EM, Jarau PO. Psicología y desastres ambientales en Chile. R Rev. Desast. socied. [internet]. 1997 [acesso em 2017 mar 15]; 5(8):78-95. Disponível em: https://www.desenredando.org/public/revistas/dys/.

74. United Nations International Strategy for Disaster Reduction. Hyogo framework for action 2005-2015: building the resilience of nations and communities disasters [internet]. 2005 [acesso em 2018 jul 8]. Disponível em: https://www.unisdr.org/.

75. United Nations International Strategy for Disaster Reduction. UNISDR. Sendai framework for disaster risk reduction 2015-2030. [internet]. 2015. [acesso em 2018 jul 8]. Disponível em: http://www.wcdrr. org/uploads/Sendai_Framework_for_Disaster_Risk_ Reduction_2015-2030.pdf.

76. Brasil. Lei ${ }^{\circ} 12.608$, de 10 de abril de 2012. Política Nacional de Proteção e Defesa Civil. Diário Oficial da União. 11 Abr 2012.

Received on 09/29/2019

Approved on 01/10/2020

Conflict of interests: non-existent

Financial support: Coordination for the Improvement of Higher

Education Personnel - Brazil (Capes) - Finance Code 001 - and

Carlos Chagas Filho Research Support Foundation of the State of

Rio de Janeiro (Faperj) - Bolsa Nota 10 Program - Doctorate 